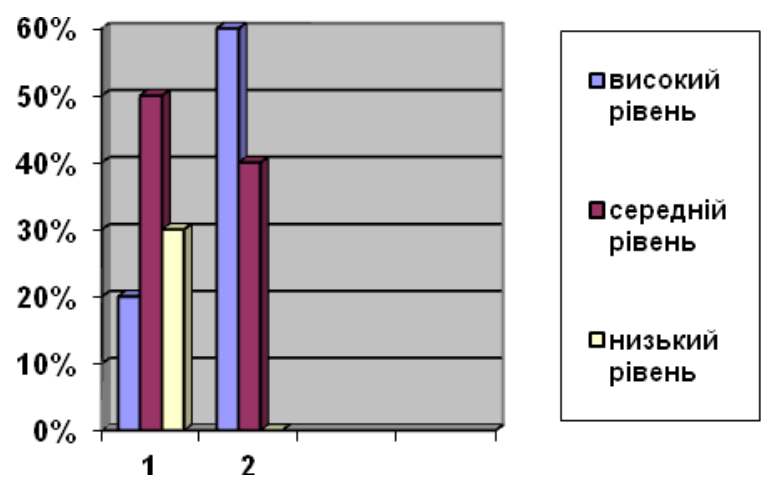

Рис. 3. Рівні сформованості зв’язного мовлення дітей контрольної та експериментальної груп

Проведене дослідження використання дитячої літератури у процесі навчання переказувати 3 дітьми 6-го року життя на заняттях із розвитку зв'язного мовлення за допомогою використання традиційної методики та різних способів моделювання виявлено позитивний результат проведеної роботи. Було зафіксовано позитивні зміни: рівень зв'язного мовлення дітей, показники обізнаності дітей дитячою літературою; набір частин мови у розповідях; показники відтворення тексту.

За результатами експерименту очевидним $\epsilon$ те, що навчання дітей старшого дошкільного віку переказувати за допомогою літератури буде ефективним за умови використання моделювання. Діти старшого дошкільного віку краще відтворюють текст твору, послідовно передають його зміст, використовують слова-замінники, що полегшує процес переказування твору. Вони 3 задоволенням виконували цю роботу, що задовольняло їхні емоційно-вольові запити.

Отже, використання дитячої літератури у процесі навчання переказувати твір із використанням способу моделювання $є$ ефективним засобом для розвитку зв'язного мовлення дітей старшого дошкільного віку.

\title{
Література
}

1. Базова програма розвитку дитини дошкільного віку «Я у Світі» / наук.кер. та заг.ред. О. Л. Кононко. - 3-тє вид.,випр. - К. : Світич, 2009. - 430 с. 2. Дошкільна лінгводидактика: Теорія і методика навчання дітей рідної мови: [підручник] / за ред. А. М. Богуш - К. : Вища шк., 2007. 542 c. 3. Зав'язун Т. В. Нетрадиційні методи роботи з казкою як засіб розвитку мовленнєвокомунікативних здібностей старших дошкільників / Т. В. Зав’язун, О. В. Семенюк // Обдарована дитина. - 2008. - № 9. - С. 41-48.

\section{ДИДАКТИЧНІ ОСОБЛИВОСТІ ПОБУДОВИ ЕФЕКТИВНОЇ ОРГАНІЗАЦІЇ КОНТРОЛЮ МАТЕМАТИЧНОЇ ПІДГОТОВКИ МАЙБУТНІХ ЕКОНОМІСТІВ}

Грибонос Є. Ю. Дидактичні особливості побудови ефективної організації контролю математичної підготовки майбутніх економістів.

У статті наголошено на необхідності розробки ефективної організації контролю навчальних досягнень майбутніх економістів у процесі вивчення математичних дисциплін на основі виявлених у сучасній практиці суперечностей та інновацій у сфері освіти. Розкриті дидактичні особливості побудови ефективної організації контролю математичної підготовки майбутніх економістів.

Ключові слова: майбутній економіст, організація контролю навчальних досягнень, математичні дисципліни. 
Грибонос Е. Ю. Дидактические особенности постороения эффективной организации контроля математической подготовки будущих экономистов.

В статье отмечена необходимость разработки эффективной организации контроля знаний будущих экономистов в процессе изучения математических дисциплин на основе выявленных в современной практике противоречий и инноваций в сфере образования. Раскрыты дидактические особенности построения эффективной организации контроля математической подготовки будущих экономистов.

Ключевые слова: будущий экономист, организация контроля учебных достижений, математические дисциплины.

Gribonos E. Y. Didactic characteristics of the effective organization of control future economists mathematical training.

The article highlighted the need to develop effective oversight of knowledge of future economists in studying mathematical disciplines based on the identified inconsistencies in current practice and innovation in education. The author revealed the didactic design features of effective oversight of mathematical training of future economists.

Key words: future economist, oversight of educational achievements, the mathematical discipline.

Одним із важливих складників процесу професійної підготовки студентів-економістів $\epsilon$ ефективна система контролю навчальних досягнень. Сучасний стан організації контролю результатів навчання майбутніх економістів у процесі вивчення математичних дисциплін має низку недоліків, які не дозволяють забезпечити математичну підготовку студентівекономістів на належному рівні. Зокрема, теоретичний аналіз психологічних та педагогічних праць, ознайомлення 3 практичним досвідом роботи вищих навчальних закладів щодо окресленої проблеми надали змогу виявити низку таких суперечностей між:

- значущістю математичної освіти у професійній діяльності майбутніх фахівців економічного профілю та недостатнім рівнем математичної підготовки студентів економічних спеціальностей;

- необхідністю вдосконалення системи контролю математичної підготовки майбутніх економістів та недостатньою розробленістю засобів контролю, спрямованих на формування професійних якостей студентів-економістів у процесі вивчення математичних дисциплін;

- орієнтацією сучасної освіти на широке використання інформаційно-комунікаційних технологій у процесі навчання і недостатнім рівнем розробленості науково-теоретичного забезпечення організації контролю математичної підготовки студентів-економістів із використанням новітніх інформаційних технологій.

Уважаємо, що ефективна організація контролю математичної підготовки майбутніх економістів має бути спрямованою саме на їх подолання, що підтверджує необхідність та актуальність подальших досліджень у цьому напрямку.

Mета статті - у межах теми «Управління якістю освітньої діяльності у вищому навчальному закладі» (державний реєстраційний номер 0107U000968), що розробляється в Луганському національному університеті імені Тараса Шевченка, вважаємо за необхідне розглянути особливості побудови системи контролю математичної підготовки майбутніх економістів та окреслити шляхи подолання виявлених суперечностей.

Організаційним початком усіх розробок є уявлення про структуру, компоненти та функціональні зв'язки педагогічної системи, яку проектують або удосконалюють [2; 3], до чого і звернемося.

Дослідженню педагогічних систем присвячені праці багатьох науковців. В узагальненому розумінні педагогічну систему подано як сукупність взаємозалежних i взаємодіючих компонентів, які утворюють стійку єдність і цілісність, що мають інтегральні властивості та закономірності. Відповідно до поглядів Н. Кузьміної [4], ми виходили 3 того, що необхідними та достатніми структурними компонентами для утворення педагогічної системи $є$ мета, зміст, засоби педагогічної комунікації (методи) та учасники педагогічного процесу. Грунтуючись на такому розумінні педагогічної системи, 
ми теоретично обгрунтовали та розробили систему контролю навчальних досягнень майбутніх економістів у процесі вивчення математичних дисциплін у вищих навчальних закладах.

Мета організації контролю зумовлюється вимогами до математичної підготовки майбутніх фахівців-економістів та, на нашу думку, полягає у визначенні рівнів навчальних досягнень майбутніх економістів у процесі опанування передбаченим навчальною програмою змістом математичних дисциплін на кожному етапі.

Щодо змісту контролю навчальних досягнень майбутніх економістів із математичних дисциплін зауважимо, що він має насамперед віддзеркалювати сутність математичних компетенцій студентів, тобто охоплювати знання та вміння, які є необхідними для здійснення математичної підготовки майбутнього економіста.

Щоб з'ясувати зміст контролю математичної підготовки майбутніх економістів, ми виокремили об'єкти перевірки, які зумовлюють визначення конкретного змісту системи контролю навчальних досягнень студентів. Основними об'єктами перевірки 3 дисциплін математичного циклу є: знання теоретичного матеріалу (теореми, правила, формули тощо); уміння використовувати набуті знання при рішенні практичних задач, зокрема у майбутній професійній діяльності та у повсякденному житті (побудова математичних моделей, розв'язування задач і вправ, рішення задач економічного змісту математичними методами та ін.); позааудиторна робота студентів (виконання індивідуальних робіт, самостійне вивчення тем тощо); уміння логічно мислити та математично грамотно викладати свої думки [6;9]. При цьому слід зауважити, що практичні вміння та навички студентів із математики спираються на теоретичні знання.

Відповідно, у систему контролю навчальних досягнень майбутніх економістів у процесі вивчення математичних дисциплін закладено такий зміст: визначення обсягу теоретичних знань, якості практичних умінь і навичок (здатність до застосування засвоєного матеріалу у майбутній професійній діяльності), а також перевірка результатів позааудиторної навчальної діяльності студентів.

Важливим компонентом педагогічної системи також є методи, за допомогою яких розкривається зміст і досягається мета функціонування системи контролю навчальних досягнень майбутніх економістів у процесі вивчення математичних дисциплін. У педагогічному словнику зазначено, що метод - це спосіб досягнення певної мети, розв'язання конкретного завдання, сукупність засобів чи операцій практичного або теоретичного освоєння (пізнання) дійсності [5, с. 313].

У сучасній педагогічній науці розроблено широку класифікацію методів контролю навчальних досягнень студентів. При цьому особливості використання кожного 3 них зумовлюються спеціфікою навчальної дисципліни, напрямком професійної підготовки майбутніх спеціалістів, а також метою контрольної дії.

Відповідно до такого розуміння мети, змісту та методів як основних компонентів педагогічної системи було розроблено систему контролю навчальних досягнень студентівекономістів у процесі вивчення математичних дисциплін у вищих навчальних закладах.

У процесі розроблення експериментальної системи контролю, спираючись на ідеї В. Бербеця [1], П. Сікорського та О. Біляковської [7; 8] та інших, ми дотримувалися таких педагогічних принципів.

Принцип природовідповідності, який передбачає під час розроблення системи контролю враховувати здатність основних учасників педагогічного процесу (викладача і студента) осмислити й адекватно сприйняти запропоновані шляхи удосконалення організації контролю навчальних досягнень студентів. Принцип природовідповідності накладає свої вимоги до побудови усіх компонентів системи контролю: шкали оцінок, критеріїв та норм оцінок, змісту контролю тощо.

Система контролю навчальних досягнень майбутніх фахівців економічних спеціальностей у процесі вивчення математичних дисциплін повинна бути зрозумілою, простою та надійною, тобто побудована на основі принципу доступності. Перш за все, iіi 
повинні сприйняти викладачі та переконатися, що вона стане доступною для розуміння всіма студентами. Якщо система контролю зрозуміла і доступна, то майбутній фахівець не шукатиме різних можливостей, як до неї адаптуватися, щоб одержати потрібні оцінки не прикладаючи особливих зусиль. Доступність системи контролю дасть можливість студенту-економісту обрати найбільш оптимальний ритм вивчення математики, проектувати свої знання на майбутню оцінку, виходячи зі своїх можливостей. Принцип доступності втілюється в рейтинговій системі контролю, причому доступність забезпечується її відкритістю.

Оскільки однією 3 вимог організації контролю навчальних досягнень студентів в умовах кредитно-модульної системи навчання $\epsilon$ забезпечення прозорості навчального процесу, при розробленні експериментальної системи контролю ми дотримуємося принципу відкритості та демократичності. Принцип відкритості передбачає повну інформованість студентів-економістів про всі компоненти системи контролю 3 математичних дисциплін: випереджувальне ознайомлення студентів зі змістом контролю, тобто зі структурою математичних знань і практичних дій, які потрібно засвоїти; зразками контрольних завдань, тестів, критеріями їх оцінювання тощо. Принцип демократичності передбачає право студента вільно висловлювати свої думки стосовно існуючої організації контролю. Це, зокрема зумовлено тим, що в умовах кредитно-модульної системи студент перетворюється 3 пасивного об'єкта в активного суб'єкта навчання та контролю. Викладач, у свою чергу, використовує право на консультування студентів під час виконання ними контрольних зрізів, індивідуальних завдань, надання слабким студентам допомоги тощо.

Принцип комплексності передбачає перевірку комплексу теоретичних знань, практичних умінь та навичок майбутніх фахівців із математичних дисциплін, а також результатів самостійної роботи студентів.

Принцип гуманітаризації передбачає таку організацію системи контролю, коли всі іiі аспекти сприяють індивідуальному розвиткові майбутнього фахівця-економіста, максимальному наближенню вивчення математичних дисциплін до майбутньої професійної діяльності.

Варто підкреслити ще один важливий принцип розроблення системи контролю: принцип науковості, який передбачає експериментальну перевірку цілісно сформованої організації контролю навчальних досягнень студентів-економістів у процесі вивчення математичних дисциплін, можливість корелювання кількості і складності навчальних завдань відповідно до вимог навчальних програм, а також інтелектуальних можливостей студентів. Принцип науковості спонукає обирати адекватні певній навчальній дисципліні методи і форми контролю.

Принцип повноти перебачає цілісність системи контролю навчальних досягнень майбутніх економістів у процесі вивчення математичних дисциплін, стійкі взаємозв'язки між її структурними компонентами.

Отже, ураховуючи визначені педагогічні принципи, суперечності та інновації у сфері освіти, розробили систему контролю навчальних досягнень майбутніх економістів у процесі вивчення математичних дисциплін, яка передбачає підвищення якості математичної підготовки студентів-економістів і складається з наступних структурних компонентів: змістово-функціональний, управлінський, технологічний.

Змістово-функціональний компонент містить мету, зміст, функції та принципи організації контролю, а також завдання контролю у процесі математичної підготовки майбутніх економістів.

Система контролю навчальних досягнень у процесі математичної підготовки майбутніх фахівців-економістів повинна виконувати низку завдань. Ми вважаємо, що окрім виокремлених нами мети, змісту, функцій та принципів функціонування системи контролю математичної підготовки майбутніх економістів, змістово-функціональний компонент доповнюється завданнями, серед яких наступні: 1) порівняння фактичних 
результатів контролю із запланованими результатами навчально-пізнавальної діяльності студентів-економістів, усунення прогалин шляхом корекції; 2) вивчення індивідуальних здібностей та особливостей студентів під час проведення корекційних заходів із метою попередження прогалин у подальшому; 3) прогнозування подальшого просування майбутніх економістів в опануванні математичним апаратом на основі результатів контролю на кожному етапі; 4) підвищення якості математичної підготовки майбутніх економістів, розвиток у них творчих здібностей, формування позитивних особистісних якостей i професійних рис засобами математики; 5) мотивування та стимулювання систематичної, цілеспрямованої навчальної роботи студентів та їх пізнавальної активності.

Технологічний компонент системи забезпечує одержання результатів контролю навчальних досягнень студентів у процесі вивчення математичних дисциплін, тобто визначає той набір засобів, за допомогою яких на всіх етапах математичної підготовки майбутніх економістів здійснюється контроль. Ми розглядаємо засоби педагогічної комунікації для здійснення контролю, технологію рейтингової оцінки, шкалу оцінювання, критерії та норми оцінки, інформаційне забезпечення з особливостей функціонування системи контролю навчальних досягнень студентів.

Управлінський компонент забезпечує управління процессом математичної підготовки майбутніх економістів через зворотний зв'язок та мотивування і стимулювання вивчення ними математики. У межах управлінського компоненту системи контролю навчальних досягнень студентів-економістів у процесі вивчення математичних дисциплін ми розглядаємо основних учасників навчально-виховного процесу та контролю - викладача та студента, їхні функції та взаємовідносини у системі контролю.

Особливості розробленої системи контролю навчальних досягнень майбутніх економістів у процесі вивчення математичних дисциплін, на відміну від існучої у сучасній практиці, полягають у використанні в процесі контролю математичної підготовки майбутніх економістів засобів новітніх інформаційних технологій та професійно спрямованих засобів контролю, які: дозволяють підвищити інтерес та мотивацію вивчення математичних дисциплін у майбутніх економістів, індивідуалізувати процес контролю, удосконалити форми та методи організації контролю навчальних досягнень студентів, сприяють більшій професійній спрямованості щодо розвитку математичних знань майбутніх економістів засобами контролю та інтелектуальних якостей студентів.

Отже, з урахуванням визначених педагогічних принципів, суперечностей та інновацій у галузі освіти розроблено систему контролю навчальних досягнень майбутніх економістів у процесі вивчення математичних дисциплін, яка передбачає підвищення якості математичної підготовки студентів-економістів і складається 3 таких структурних компонентів: змістово-функціональний, управлінський, технологічний. Розглянуто дидактичні особливості побудови ефективної організації контролю математичної підготовки майбутніх економістів.

Перспективні завдання полягають у дослідженні проблеми ефективної організації контролю математичної освіти студентів різних напрямків підготовки.

\section{Література}

1. Бербец В. В. Методика діагностування навчальних досягнень учнів 5-9 класів на уроках трудового навчання : дис. ... канд. пед. наук : 13.00.02 / Бербец Віталій Васильович. - Умань, 2005. - 184 с. 2. Беспалько В. П. Параметры и критерии диагностичной цели / В. П. Беспалько // Школьные технологии. - 2006. - № 1. - С. 118-128. 3. Беспалько В. П. Системно-методическое обеспечение учебно-воспитательного процесса подготовки специалистов : [учеб.-метод. пособие] / В. П. Беспалько, Ю. Г. Татур. - М. : Высш. шк., 1989. - 144 с. 4. Методы системного педагогического исследования : [учебное пособие] / [под. ред. Н. В. Кузьминой]. - Л. : Изд-во Ленинград. ун-та, 1980. - 172 с. 5. Педагогічний словник / [за ред. М. Ярмаченка]. - К. : Педагогічна думка, 2001. - 516 с. 6. Сергієнко Н. В. Контроль знань студентів у системі MOODLE при вивченні вищої математики / Н. В. Сергієнко // Проблеми впровадження кредитно-модульної системи при вивченні фундаментальних дисциплін очима студентів та викладачів : [матеріали 
Всеукраїнської наук.-практ. конф. (Харків, 14-16 травня 2007 р.)]. - Харків, 2007. - С. 61-65. 7. Сікорський П. Принципи моделювання оцінювальних систем / Петро Сікорський, Ольга Біляковська // Шлях освіти. - 2006. - № 1. - С. 14-17. 8. Сікорський П. Моделювання дидактичних систем оцінювання / Петро Сікорський, Ольга Біляковська // Шлях освіти. - 2006. № 2. - С. 2-6. 9. Харитонова И. В. Рейтинговая система контроля математических знаний студентов : дис. ... канд. пед. наук : 13.00.02. / Харитонова Ирина Владимировна. - Москва, 2003. $-185 \mathrm{c}$.

УДК 378.147:004

С. М. Грищенко,

здобувач,

ДВНЗ «Криворізький наиіональний університет»

\section{ФОРМУВАННЯ ТВОРЧОГО ПІДХОДУ ДО НАВЧАННЯ}

Грищенко С. М. Формування творчого підходу до навчання.

У статті висвітлюється проблема формування творчого підходу викладача до організації навчального процесу і творчого ставлення студентів до навчання в предметно-орієнтованому комп'ютерному середовищі.

Ключові слова: творчість, предметно-орієнтоване комп'ютерне середовище, інформаційні технології, навчально-рольова гра.

Грищенко С. М. Формирование творческого подхода к обучению.

В статье освещается проблема формирования творческого подхода преподавателя к организации учебного процесса и творческого отношения студентов к обучению в предметноориентированной компьютерной среде.

Ключевые слова: творчество, предметно-ориентированная компьютерная среда, информационные технологии, учебно-ролевая игра.

Grischenko S. M. Forming creative approach to teaching.

The article highlights the problem of the creative teacher to the educational process and creative approach to teaching students in object-oriented computing environment.

Key words: creativity, object-oriented computing environment, information technology, training and role-playing game.

Інтенсивний розвиток інформаційних технологій вимагає більш високого наукового, технологічного й гуманітарного рівня підготовки фахівців. Виникає потреба у фахівцях, що володіють системою наукових знань, уміннями і навичками самостійної роботи, творчим ставленням до навчання і праці.

У суспільному житті часто виникають проблемні ситуації, для розв’язання яких слід застосовувати знання та вміння, накопичені у процесі навчання. Однак пропонована для засвоєння навчальна інформація становить систему абстрактних, формальних відомостей (у вигляді тексту, моделей, знакових систем), які рідко можна використати на практиці в чистому вигляді. Отже, в освітньому процесі необхідно акцентувати увагу на формуванні у студентів навичок здійснювати перенесення та використання відомих способів діяльності в новій ситуації, на готовність до пошуку розв'язання нових проблем, що виявами творчості.

Вивчення процесу становлення творчої особистості, здатної самостійно мислити і приймати відповідальні рішення, має наукову та практичну актуальність.

Різні науковці трактують по-різному можливість і правомірність навчання творчості. Одні автори вважають, що процес творчості неповторний, унікальний, що його неможливо зімітувати (А. Брушлинський). Інші (Г. Альтшуллер, І. Волков. В. Мерцалова, В. Розумовський, Ю. Саламатов, А. Уразова) дотримуються думки, що процес творчості цілком керований, що творчості необхідно і можна вчити. У роботах В. Андреєва, I. Лернера, О. Цибулі, Дж. Ніренберга, А. Шевирьова наголошується на можливості 